INDONESIA ACCOUNTING JOURNAL

VOLUME 2, NUMBER 1, YEAR 2020

${ }^{1}$ Corresponding author

Jurusan Akuntansi

Fakultas Ekonomi dan Bisnis

Universitas Sam Ratulangi

Jl. Kampus UNSRAT

Manado, Indonesia, 95115

E-mail: kezsyalendra@gmail.com

${ }^{2,3}$ Jurusan Akuntansi

Fakultas Ekonomi dan Bisnis

Universitas Sam Ratulangi

Jl. Kampus UNSRAT

Manado, Indonesia, 95115

Article info:

Received 13 January 2020

Accepted 13 January 2020

Available online 13 January 2020

Keywords: regional financial capability; financial independence; financial dependency

JEL Classification: H11, H83

DOI: http://doi.org/10.3240o/iaj.27174

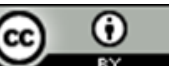

\section{Analisis perkembangan kemampuan keuangan daerah pada Pemerintah Provinsi Sulawesi Utara tahun anggaran 2014-2018。}

\author{
Keren Kezia Rejoice Adlin Mamangkey ${ }^{1}$ \\ Hendrik Manossoh ${ }^{2}$ \\ Heince Rudy Nicky Wokas ${ }^{3}$
}

\begin{abstract}
This study aims to determine how the development of regional financial capability in the North Sulawesi provincial government from its level of independence, level of dependency, decentralization ratio, and financial growth. The main characteristic of the region's ability to organize its government is the ability in its finances to finance the administration of the regional government. This type of research is qualitative research. Descriptive method is an analytical method used in this thesis research, that is every data - data obtained, analyzed based on theories relevant to the problem to be discussed to obtain the results of the analysis which is then concluded and provides advice. The results of descriptive analysis of the North Cellebes Province LRA APBD data show that from 2014 to 2018, the Regional Original Revenue development is still lacking, has not experienced a significant increase because Transfer Funds still dominate the Regional Revenue of North Cellebes Province. The conclusion is that there has been an improvement even though it is lacking, but based on the calculation of the financial ratios the Financial Ability is still in the near-able valuation.
\end{abstract}

\section{Pendahuluan}

Terwujudnya Sulawesi Utara berdikari dalam ekonomi, berdaulat dalam politik dan berkepribadian dalam budaya, merupakan Visi Pembangunan Provinsi Sulawesi Utara 2015-2020. Berdasarkan Visi Pemerintah Daerah Provinsi Sulawesi Utara Tahun 2016-2021, yang salah satunya adalah berdikari dalam ekonomi dan hal tersebut menggambarkan bagaimana Pemerintah Daerah Provinsi Sulawesi Utara di bawah kepemimpinan Gubernur Olly Dondokambey, SE dan Wakil Gubernur Drs. Steven Kandow (OD-SK) ingin mendukung Pemerintah dalam pelaksanaan Otonomi Daerah seperti yang tertuang dalam Undang-undang Nomor 32 tahun 2004 tentang Pemerintah Daerah yang telah diserahkan sejumlah kewenangan dari Pemerintah Pusat ke Pemerintah Daerah yang bersangkutan untuk mengurus dan mengatur kepentingan masyarakat setempat menurut prakarsa sendiri berdasarkan aspirasi masyarakat sesuai dengan peraturan perundang-undangan. Berdikari dalam Ekonomi artinya Pemerintah Daerah memiliki kemampuan menjadi daerah yang mandiri karena kuat dan mampu dalam keuangannya sehingga memiliki kemampuan keuangan daerah yang mandiri untuk meminimalisasikan ketergantungan keuangan dari pihak luar.

Berdasarkan Penjelasan Umum UU Nomor 32 Tahun 2004 bahwa sesuai dengan amanat UUD Negara Republik Indonesia Tahun 1945, Pemerintah Daerah berwenang untuk mengatur dan mengurus sendiri urusan pemerintahan menurut asas otonomi dan tugas pembantuan karena tujuan daripada otonomi daerah adalah agar daerah tersebut dapat tentunya mengatur dan mengurus daerah sendiri agar dapat meningkatkan Potensi Daerah yang ada untuk penyelenggaraan pemerintahan dalam Pembangunan dan memaksimalkan pelayanan terhadap masyarakat di daerah tersebut. 
Kemampuan dalam menggali setiap potensi-potensi daerah yang setiap tahunnya ada perkembangan dalam penerimaan bisa menghasilkan kekayaan bagi daerah tersebut untuk menjadi sumber Pendapatan Asli Daerah serta memiliki kemampuan dalam mengelola keuangan daerah, merupakan suatu penilaian terhadap kemampuan daerah tersebut. Jika daerah tersebut memiliki perkembangan akan kemampuan terhadap keuangannya, hal tersebut akan membawa pengaruh terhadap pertumbuhan pembangunan dan kesejahteraan masyarakat, baik dalam jangka pendek maupun jangka panjang. Suatu daerah akan disebut daerah yang memiliki Kemampuan Keuangan atau tidak, tergantung pada bagaimanan daerah tersebut mengelola kekayaan daerahnya dan keuangannya sehingga daerah tersebut memiliki pertumbuhan setiap tahunnya dalam pendapatan asli daerahnya sehingga memiliki kemandirian dalam keuangannya dan tidak sepenuhnya bergantung terhadap dana transferan dari pihak luar atau pemerintah pusat.

\section{Tinjauan pustaka}

Konsep akuntansi. Akuntansi adalah suatu sistem, yang tujuannya adalah menghasilkan informasi dalam bentuk laporan keuangan bagi pihak-pihak yang berkepentingan (Pontoh, 2013). Laporan keuangan yang dihasilkan oleh akuntansi keuangan daerah terdiri atas laporan perhitungan APBD, nota perhitungan APBD, laporan aliran kas, dan neraca. Akuntansi selain merupakan sistem, juga merupakan siklus. Artinya, akuntansi terdiri atas tahap-tahap tertentu dan setelah selesainya tahap-tahap tersebut, kegiatan berulang kembali sesuai dengan urutan tersebut. Tahap-tahap yang terdapat dalam siklus akuntansi adalah analisis transaksi, jurnal, posting, neraca saldo, penyesuaian, neraca saldo setelah penyesuaian, laporan keuangan, penutupan, dan neraca saldo setelah penutupan.

Laporan keuangan daerah. Laporan Keuangan pemerintah daerah adalah gambaran mengenai kondisi dan kinerja keuangan entitas tersebut. Salah satu pengguna laporan keuangan pemerintah daerah adalah pemerintah pusat. Hal ini disebabkan karena pemerintah pusat telah menyerahkan sumber daya keuangan kepada daerah dalam rangka pelaksanaan otonomi daerah. Komponen dari Laporan Keuangan Pemerintah Daerah (LKPD) adalah: Laporan Realisasi Anggaran (LRA), Laporan Neraca, Laporan Arus Kas (LAK), dan Catatan Atas Laporan Keuangan. Salah satu komponen Laporan Keuangan Pemerintah adalah Laporan Realisasi Anggaran (LRA) yang merupakan pelaporan pertanggungjawaban realisasi anggaran untuk suatu periode tertentu dalam rangka untuk memenuhi tujuan akuntabilitas anggaran pemerintah berdasarkan peraturan perundang-undangan.

Pemerintah Daerah. Undang-undang Nomor 23 Tahun 2014 tentang Pemerintahan Daerah Bab I Pasal 1 ayat 2 dan 3 : "Pemerintahan Daerah adalah penyelenggaraan urusan pemerintahan oleh pemerintah daerah dan dewan perwakilan rakyat daerah menurut asas otonomi dan tugas pembantuan dengan prinsip otonomi seluas-luasnya dalam sistem dan prinsip Negara Kesatuan Republik Indonesia sebagaimana dimaksud dalam UndangUndang Dasar Negara Republik Indonesia Tahun 1945 dan Pemerintah Daerah adalah Kepala Daerah sebagai unsur penyelenggara Pemerintahan Daerah yang memimpin pelaksanaan urusan pemerintahan yang menjadi kewenangan daerah otonom". Artinya pemerintah daerah dapat mengatur dan mengelola sendiri urusan pemerintahan di wilayahnya menurut asas otonomi dan tugas pembantuan dengan prinsip otonomi untuk meningkatkan kesejahteraan masyarakat dibawah komando Kepala Daerah dan Dewan Perwakilan Rakyat Daerah.

Asas Pemerintah Daerah. Asas desentralisasi adalah penyerahan wewenang penyelenggaraan pemerintahan oleh Pemerintah Pusat kepada Pemerintah Daerah otonom untuk mengatur dan mengurus urusan pemerintahan dalam sistem Negara Kesatuan Republik Indonesia. Asas Dekonsentrasi, yaitu 
pelimpahan wewenang pemerintahan oleh Pemerintah Pusat kepada Gubernur sebagai wakil pemerintah dan/atau kepada instansi vertikal di wilayah tertentu. Asas Tugas Pembantuan, yaitu penugasan dari pemerintah provinsi kepada pemerintah kabupaten atau kota dan atau desa, serta dari pemerintah kabupaten atau kota kepada desa untuk melaksanakan tugas tertentu.

Keuangan Daerah. Peraturan Pemerintah Nomor 105 Tahun 2000, menjelaskan bahwa Keuangan Daerah adalah semua hak dan kewajiban daerah dalam rangka penyelenggaraan pemerintah daerah yang dapat dinilai dengan uang temasuk didalamnya segala bentuk kekayaan lain yang berhubungan dengan hak dan kewajiban daerah tersebut dalam kerangka APBD. Undang-Undang Republik Indonesia Nomor 32 Tahun 2004 Dalam Penjelasan Umum Pasal 156 Ayat (1), tentang Keuangan Daerah adalah: "Semua hak dan kewajiban daerah yang dapat dinilai dengan uang dan segala sesuatu berupa uang dan barang yang dapat dijadikan milik daerah yang berhubungan dengan pelaksanaan hak dan kewajiban tersebut". Oleh karena pentingnya kedudukan keuangan tersebut, maka salah satu indikator adalah keuangan daerah agar dapat diketahui akan kemampuan daerah dalam mengelola dan mengurus rumah tangganya sendiri. Namun dengan adanya undang-undang otonomi daerah akan muncul konsekuensi perbedaan pada kemampuan keuangan daerah dalam menyelenggarakan otonomi daerah.

Pendapatan Daerah. Setiap program pembangunan yang dijalankan oleh pemerintah tentunya memerlukan banyak dana. Dalam pembiayaan pembangunan tersebut dihimpun dari berbagai sumbersumber pendapatan atau penerimaan untuk penyelenggaraan pembangunan suatu negara ataupun suatu daerah dan. sumber-sumber penerimaan dan pengalokasiannya dapat dilihat dari setiap susunan APBN maupun APBD yang telah diatur berdasarkan Peraturan perundang-undangan maupun peraturan daerah. Dalam Undang-undang Nomor 32 Tahun 2004 tentang
Pemerintahan daerah dijelaskan bahwa sumber pendapatan daerah terdiri atas : 1) Pendapatan Asli Daerah; 2) Dana Perimbangan; dan 3) Lain-lain pendapatan daerah yang asli.

Pendapatan Asli Daerah. Pendapatan Asli Daerah adalah hak pemerintah daerah yang diakui sebagai penambah nilai kekayaan bersih yang diperoleh dari Pajak Daerah, Retribusi Daerah, Hasil Pengelolaan Kekayaan Daerah yang Dipisahkan serta Lain-lain Pendapatan Asli Daerah yang Sah, sebagaimana yang tercantum dalam UndangUndang Nomor 23 Tahun 2004 tentang Pemerintahan Daerah pada Pasal 285 ayat (1), Peraturan Pemerintah Nomor 58 Tahun 2005 tentang Pengelolaan Keuangan Daerah pada Pasal 21 ayat (1) dan Peraturan Menteri Dalam Negeri Nomor 13 Tahun 2006 tentang Pedoman Pengelolaan Keuangan Daerah pada Pasal 26 ayat (1). UndangUndang Nomor 33 Tahun 2004, Bab I (pasal 1) tentang Perimbangan Keuangan antara Pemerintah Pusat dan Pemerintah Daerah, menjelaskan bahwa Pendapatan Asli Daerah, selanjutnya disebut PAD adalah pendapatan yang diperoleh Daerah yang dipungut berdasarkan Peraturan Daerah sesuai dengan peraturan perundangundangan. Artinya Pendapatan Asli Daerah (PAD) merupakan semua penerimaan daerah yang berasal dari sumber ekonomi asli daerah yang dipungut berdasarkan Peraturan Daerah dan tentunya mengacu dari peraturan perundang-undangan yang berlaku.

Dana Perimbangan. Dana Perimbangan menurut UU Nomor 33 Tahun 2004, meliputi :

1. Dana Alokasi Khusus (DAK). Dialokasikan ke daerah dengan tujuan membantu dalam pembiayaan kebutuhan khusus, seperti kebutuhan yang merupakan urusan daerah atau kebutuhan prioritas Nasional.

2. Dana Alokasi Umum (DAU). Dana yang berasal dari APBN yang dialokasikan dengan tujuan pemerataan kemampuan keuangan antar daerah untuk mendanai kebutuhan pengeluarannya sehingga tidak tercipta ketimpangan kebutuhan 
pembiayaan penyelenggaraan pemerintahan daerah dalam rangka pelaksanaan desentralisasi.

3. Dana Bagi Hasil (DBH) Pajak/Bukan Pajak. Digunakan untuk mengatasi masalah ketimpangan vertikal antara pemerintah pusat dan pemerintah daerah.

Lain-lain Pendapatan Daerah Yang Sah. Lain-lain pendapatan Daerah yang sah meliputi, Dana Hibah, Dana Darurat, Dana Bagi Hasil Pajak dari Provinsi dan Pemerintah Daerah lainnya, Dana Penyesuaian dan Otonomi Khusus, Bantuan Keuangan dari Provinsi atau Pemerintah Daerah lainnya dan Pendapatan lain-Lain.

\section{Pengelolaan Keuangan Daerah.}

Dasar hukum pengelolaan keuangan daerah adalah:

1) UU No. 32 Tahun 2004 tentang Pemerintahan Daerah.

2) UU No. 33 Tahun 2004 tentang Perimbangan Keuangan antara Pemerintah Pusat dan Daerah.

3) PP No. 24 Tahun 2005 tentang Standar Akuntansi Pemerintah.

4) PP No. 58 Tahun 2005 tentang Pengelolaan Keuangan Daerah.

5) Permendagri No. 13/2006 tentang Pedoman Pengelolaan Keuangan Daerah.

6) Peraturan Pemerintah Nomor 12 tahun 2019 tentang Pengelolaan Keuangan Daerah.

7) UU Nomor 33 Tahun 2014, Bab IX tentang Pengelolaan Keuangan dalam rangka Desentralisasi.

Anggaran Pendapatan dan Belanja Daerah (APBD). Anggaran Pendapatan Belanja Daerah yang tertulis dalam UndangUndang No. 32 Tahun 2004, merupakan rencana keuangan setiap tahunnya pemerintah daerah yang dibahas bersama dan disetujui bersama oleh pemerintah daerah dan Dewan Perwakilan Rakyat Daerah, kemudian ditetapkan dalam peraturan daerah. Dalam penerapannya APBD dapat menggambarkan kebutuhan dan kemampuan setiap daerah sesuai dengan keunikan dan potensinya tersendiri dan dalam penyelenggaraan pemerintahan daerah, setiap penerimaan dan pengeluaran keuangan daerah semuanya tercantum dalam Anggaran Pendapatan dan Belanja Daerah yang tentunya ditata sesuai dengan peraturan perundang-undangan.

Kemampuan Keuangan Daerah. Kemampuan keuangan daerah adalah kemampuan dan kewenangan daerah dalam menggali sumber-sumber pendapatan di daerahnya dengan melihat potensi-potensi daerah yang adalah kekayaan daerah yang bisa dijadikan sumber pendapatan asli daerah dan mampu mengelola keuangannya dengan tepat guna untuk pembiayaan penyelenggaraan daerahnya dengan mandiri. Kemandirian keuangan daerah adalah "Kemampuan pemerintah daerah dalam membiayai sendiri kegiatan pemerintahan, pembangunan dan pelayanan kepada masyarakat yang telah membayar pajak dan retribusi sebagai sumber pendapatan yang diperlukan daerah (Halim, 2008:232). Pemerintah daerah di dorong untuk memiliki tanggung jawab terhadap pengelolaan keuangan daerah (Savitry et al. 2011).

Analisis Rasio Keuangan Terhadap Perkembangan Kemampuan Keuangan Daerah. Analisis Rasio Keuangan adalah usaha mengidentifikasi ciri-ciri keuangan berdasarkan laporan keuangan yang tersedia. Dalam mengadakan analisis keuangan memerlukan ukuran tertentu. Ukuran yang sering digunakan adalah rasio. Menurut Helfert (2000), Rasio adalah suatu angka yang menunjukkan hubungan suatu unsur dengan unsur lainnya dalam laporan keuangan, sedangkan menurut Munawir (1997), rasio sebagai hubungan atau perimbangan antara satu jumlah tertentu dengan jumlah yang lain. Untuk menganalisis perkembangan kemampuan keuangan pemerintah daerah yang tercatat dalam Laporan Realisasi Anggaran Pendapatan dan Belanja Daerah (APBD), ada berbagai analisis rasio keuangan yang dilakukan agar dapat terlihat dengan jelas seberapa besar perkembangan dan kemampuan keuangan daerah. Kemandirian Keuangan menunjukkan tingkat kemampuan suatu daerah dalam menggali 
sumber-sumber pendapatan asli daerah dan mampu mengelolanya dengan baik dalam rangka membiayai sendiri akan kegiatan penyelenggaraaan pemerintah di daerahnya. Rasio Kemandirian Keuangan Daerah ditunjukkan oleh besarnya Pendapatan Asli Daerah dibandingkan dengan Pendapatan Transfer dan semakin tinggi angka rasio kemandirian keuangannya, menunjukkan bahwa pemerintah daerah semakin tinggi kemandirian keuangan daerahnya. Rasio Ketergantungan. Pemerintah Daerah diharapkan mampu menggali setiap potensi daerah untuk meningkatkan Pendapatan Asli Daerah agar Ketergantungan Keuangan terhadap transferan dana dari pemerintah pusat dapat berkurang dari tahun ke tahun. Rasio Ketergantungan Keuangan Daerah dapat dihitung dengan cara membandingkan jumlah pendapatan transfer yang diterima dengan total pendapatan daerah. Jika Rasio Ketergantungan ini semakin tinggi maka hal tersebut menunjukkan besarnya tingkat ketergantungan pemerintah daerah terhadap Rasio Derajat Desentralisasi Fiskal (DDF). Derajat desentralisasi dilihat dari perbandingan PAD dengan Total Pendapatan Daerah (TPD). Mahmudi (2010: 142) mengatakan bahwa: "Derajat desentralisasi dihitung berdasarkan perbandingan antar jumlah Pendapatan Asli Daerah dengan total penerimaan daerah. Rasio ini menunjukkan derajat kontribusi PAD terhadap total penerimaan daerah. Semakin tinggi kontribusi PAD maka semakin tinggi kemampuan pemerintah daerah dalam menyelenggarakan desentralisasi. Rasio Pertumbuhan. Untuk dapat mengetahui seberapa besar kemampuan keuangan daerah Pemerintah Provinsi Sulawesi Utara dalam mempertahankan dan mengembangkan keberhasilan pemerintah dalam menyelenggarakan pembangunan yang telah dicapai dari periode ke periode berikutnya. Melalui perhitungan Rasio Pertumbuhan ini, akan terlihat pertumbuhan Pendapatan Daerah, Belanja Modal, Belanja Operasi, apakah terjadi perkembangan dari tahun ke tahun dalam lima tahun terakhir di Pemerintah Provinsi Sulawesi Utara.

\section{Metode penelitian}

Jenis penelitian. Penelitian ini menggunakan jenis penelitian kualitatif. Jenis Penelitian kualitatif dapat menghasilkan data deskriptif dalam bentuk uraian kata-kata atau lisan yang merupakan hasil dari analisis data kemudian disimpulkan menjadi jawaban dari permasalahan yang diteliti dan bisa dipertanggungjawabkan. Data yang dikumpulkan terarah pada dokumendokumen tersedia yang akan dianalisis dipelajari dan ditafsirkan dengan usaha memahami maknanya sesuai dengan sudut pandang sumber datanya.

Jenis Data. Jenis data yang digunakan dalam penelitian ini menggunakan data Primer yang diperoleh secara langsung dari hasil penelitian melalui wawancara pada unit penelitian dan data sekunder runtun waktu (time series) tahunan dalam bentuk Laporan Realisasi Anggaran Pendapatan dan Belanja Daerah Provinsi Sulawesi Utara dari Periode Tahun Anggaran 2014 sampai dengan 2018.

Sumber Data. Sumber data yang digunakan dalam penelitian ini adalah Data Primer, yaitu data yang diperoleh secara langsung dari hasil penelitian melalui wawancara pada unit penelitian yaitu Badan Keuangan dan Aset Daerah Provinsi Sulawesi Utara. Data Sekunder, merupakan data yang diperoleh secara tidak langsung yang ditulis berdasarkan laporan atau data yang telah dipublikasikan, seperti : catatan atau dokumentasi dalam bentuk Laporan Realisasi APBD tahun 2014 sampai dengan tahun 2018 yang telah dipublikasikan, bukubuku literatur yang digunakan sebagai acuan, jurnal penelitian. Undang-undang dan Peraturan tentang Pemerintah Daerah dan Keuangan Daerah.

Metode Pengumpulan Data. Metode pengumpulan data dalam penelitian ini berbentuk: Observasi, Wawancara, dan Dokumentasi.

Metode Analisis Data. Penelitian ini dalam menganalisis data, menggunakan Metode Analisis Deskriptif. Dalam analisis ini akan dideskripsikan bagaimana kondisi dari perkembangan kemampuan keuangan daerah Provinsi Sulawesi Utara pada waktu tertentu dengan menggunakan data Laporan 
Realisasi Anggaran Pendapatan dan Belanja Daerah tahun 2014 sampai dengan tahun 2018.

\section{Hasil penelitian dan pembahasan \\ Hasil penelitian}

Rasio Kemandirian Keuangan

Daerah. Kemandirian keuangan daerah dapat dilihat dari besarnya PAD dibandingkan dengan penerimaan Dana Transfer dari pusat.

$$
\text { Rasio Kemandirian }=\frac{\text { Pendapatan Asli Daerah }(\mathrm{PAD})}{\text { Dana Transferan }} \times 100 \%
$$

Tabel 1. Rasio Kemandirian Keuangan Provinsi Sulawesi Utara Tahun Anggaran 2014 - 2018 (dinyatakan dalam ribuan rupiah)

\begin{tabular}{crrr}
\hline Tahun & PAD (Rp) & Dana Transfer (Rp) & Rasio Kemandirian (\%) \\
\hline 2014 & 937.681 .927 & 1.093 .949 .318 & $85,7 \%$ \\
2015 & 1.012 .945 .961 & 1.173 .041 .387 & $86,3 \%$ \\
2016 & 981.044 .550 & 1.880 .906 .287 & $52,1 \%$ \\
2017 & 1.146 .674 .828 & 2.508 .041 .622 & $45,7 \%$ \\
2018 & 1.168 .433 .686 & 2.586 .412 .080 & $45,2 \%$ \\
& & Rata-rata/Tahun & $63 \%$ \\
\hline
\end{tabular}

Sumber Data : APBD Provinsi Sulut 2019

Pada Tabel 1, dapat dilihat dan diketahui akan rasio kemandirian keuangan daerah Provinsi Sulawesi Utara dalam lima tahun terakhir ini, yaitu tahun anggaran 2014 sampai dengan 2018. Pada periode tahun 2014 rasio kemandirian yang di hasilkan yaitu sebesar $85,7 \%$. Pada periode tahun 2015 rasio kemandirian pada posisi jumlah prosentasi yang hanya naik sedikit $0,6 \%$ sehingga menjadi $86,3 \%$, namun pada periode tahun 2016 rasio kemandirian mengalami penurunan sebesar 34,2\% sehingga ada pada angka 52,1\% dan pada periode tahun 2017 terus menurun sebanyak $6,4 \%$, hanya mencapai $45,7 \%$ dan pada periode 2018 hanya menurun 0,5\% sehingga menjadi 45,2\%. Dalam perhitungan untuk 5 Tahun Anggaran dari tahun 2014 2018, Rasio Kemandirian Keuangan Daerah di Provinsi Sulawesi Utara untuk rata-rata pertahunnya mencapai pada angka $63 \%$. Berdasarkan hasil dari perhitungan rasio kemandirian keuangan yang diukur dari besarnya Pendapatan Asli Daerah dibagi dengan penerimaan Dana Transfer, menghasilkan rata-rata pertahunnya pada angka 63\%. Jika diukur berdasarkan pola hubungan untuk tingkat kemandirian keuangan yang ada pada pencapaian 63\%, dapat dikategorikan kemandirian keuangannya memiliki pola hubungan yang Partisipatif artinya peranan pemerintah pusat semakin berkurang karena kemampuan keuangannya ada pada kategori sedang, sekalipun perkembangan dari besarnya penerimaan PAD belum terjadi peningkatan yang signifikan dari tahun ke tahun sepanjang tahun anggaran 2014 - 2018.

Rasio Ketergantungan Keuangan Daerah. Rasio ketergantungan daerah menggambarkan seberapa besar tingkat ketergantungan suatu daerah terhadap bantuan dana pihak luar. Semakin tinggi ketergantungan suatu daerah, semakin tinggi tingkat ketergantungan daerah terhadap bantuan Pusat/pihak luar. Rasio Ketergantungan dapat dilihat dari besarnya Pendapatan Dana Transfer dibandingkan dengan Total Pendapatan yang diterima. 


$$
\text { Rasio Ketergantungan }=\frac{\text { Pendapatan Transfer }}{\text { Total Pendapatan }} \times 100 \%
$$

Tabel 2. Rasio Ketergantungan Provinsi Sulawesi Utara Tahun Anggaran 2014 - 2018 (dinyatakan dalam ribuan rupiah)

\begin{tabular}{ccrr}
\hline Tahun & $\begin{array}{c}\text { Pendapatan Dana } \\
\text { Transfer }\end{array}$ & $\begin{array}{c}\text { Total Pendaptan } \\
\text { Daerah }\end{array}$ & $\begin{array}{c}\text { Rasio } \\
\text { Ketergantungan }\end{array}$ \\
\hline 2014 & 1.093 .949 .318 & 2.320 .810 .783 & $47,1 \%$ \\
2015 & 1.173 .041 .387 & 2.527 .959 .070 & $46,4 \%$ \\
2016 & 1.880 .906 .287 & 2.885 .186 .111 & $65,2 \%$ \\
2017 & 2.508 .041 .622 & 3.731 .901 .683 & $67,2 \%$ \\
2018 & 2.586 .412 .080 & 3.779 .295 .766 & $68,4 \%$ \\
& & Rata-rata/tahun & $58,86 \%$ \\
\hline
\end{tabular}

Sumber Data : APBD Provinsi Sulut 2019

Hasil dari perhitungan Rasio Ketergantungan Keuangan Daerah Provinsi Sulawesi Utara dapat dilihat pada Tabel 2 dan untuk tahun 2014 yaitu sebesar 47,1\% dan di di tahun 2015 menurun $0.7 \%$ sehingga ada pada angka 46,4\%, pada tahun 2016 mengalami peningkatan 18,8\% sehingga mencapai pada jumlah $65,2 \%$ dan pada tahun 2017 terus meningkat sekalipun hanya $2 \%$ sehingga mencapai $67,2 \%$ dan pada tahun 2018 merupakan angka tertinggi, naik 1,2\% sehingga mencapai pada jumlah $68,4 \%$. Jika diakumulasikan pencapaian angka tersebut selama tahun anggara 2014 2018, mendapatkan hasil untuk rata-rata pertahunnya pada angka 58,86\%. Berdasarkan kriteria penilaian untuk ratarata pertahun sebesar 58,86\%, Ketergantungan Keuangan Daerah Provinsi Sulawesi Utara tahun 2014 - 2018 terhadap dana transfer dari pusat ada pada kategori sangat tinggi, karena perkembangan penerimaan dari total pendapatan daerah yang begitu signifikan menunjukan bahwa kontribusi terbesar masih tetap dikuasai oleh penerimaan yang berasal dari Pendapatan Dana Transfer/Dana Perimbangan.

Rasio Derajat Desentralisasi Fiskal. Rasio ini dimaksudkan untuk mengukur tingkat kontribusi Pendapatan Asli Daerah sebagai sumber pendapatan yang dikelola sendiri oleh daerah terhadap total penerimaan daerah karena semakin tinggi kontribusi Pendapatan Asli Daerah (PAD), maka semakin tinggi pula kemampuan pemerintah daerah dalam menyelenggarakan desentralisasi. Untuk perhitungan Derajat desentralisasi fiskal, komponen PAD dibandingkan dengan TPD (Total Penerimaan Daerah).

$$
\text { Derajat Desentralisasi }=\frac{\text { Pendapatan Asli Daerah }}{\text { Total Pendapatan Daerah }} \times 100 \%
$$

Tabel 3. Rasio Desentralisasi Fiskal Provinsi Sulawesi Utara Tahun Anggaran 2014 - 2018 (dinyatakan dalam ribuan rupiah)

\begin{tabular}{crrr}
\hline Tahun & $\begin{array}{c}\text { Pendapatan Asli Daerah } \\
\text { (PAD) }\end{array}$ & $\begin{array}{c}\text { Total Pendapatan } \\
\text { Daerah (TPD) }\end{array}$ & $\begin{array}{c}\text { Rasio Desentralisasi } \\
\text { Fiskal }\end{array}$ \\
\hline 2014 & 937.681 .927 & 2.320 .810 .783 & $40 \%$ \\
2015 & 1.012 .945 .961 & 2.527 .959 .070 & $40 \%$ \\
2016 & 981.044 .550 & 2.885 .186 .111 & $34 \%$ \\
2017 & 1.146 .674 .828 & 3.731 .901 .683 & $31 \%$ \\
2018 & 1.168 .433 .686 & 3.779 .295 .766 & $31 \%$ \\
& & Rata-rata & $35,2 \%$ \\
\hline Sumber Data
\end{tabular}


Berdasarkan Tabel 3 terlihat bahwa Rasio Derajat Desentralisasi Fiskal Daerah Provinsi Sulawesi Utara di tahun 2014 mencapai besaran 40\%, di tahun 2015 masih tetap sama $40 \%$, tidak ada perkembangan dalam capaian dan di tahun 2016 terjadi penurun $6 \%$ sehingga menjadi $34 \%$, dan di tahun 2017 - 2018 mengalami penurunan $3 \%$, menjadi $31 \%$ sehingga jika dirataratakan pertahun untuk Derajat Desentralisasi dalam lima tahun terakhir hanya mencapai angka 35,2\%. Menurut hasil penemuan Tim Fisipol UGM menggunakan skala interval untuk Krieteria Penilaian Tingkat Desentralisasi Fiskal, sebagaimana yang terlihat dalam Tabel 3 terlihat bahwa Rasio Derajat Desentralisasi selama tahun 2014 - 2018 pada Pemerintah Daerah Provinsi Sulawesi Utara, jika dilihat dari Kriteria Penilaiannya masih dalam penilaian yang cukup, karena berada dalam skala interval antara 30,01- 40,00 yaitu sebesar $35,2 \%$, ini berarti bahwa sekalipun dari perhitungan Rasio Desentralisasi Fiskal terjadi penurunan kontribusi PAD terhadap Total Pendapatan Daerah, namun Pendapatan Asli Daerah (PAD) masih ada pada kategori cukup memiliki kemampuan keuangannya dalam menjalankan desentralisasi.

\section{Rasio Pertumbuhan Keuangan.} Untuk dapat mengetahui seberapa besar kemampuan keuangan daerah Pemerintah Provinsi Sulawesi Utara dalam mempertahankan dan mengembangkan keberhasilan pemerintah dalam menyelenggarakan pembangunan yang telah dicapai dari periode ke periode berikutnya, maka penelitian ini menggunakan perhitungan melalui analisis Rasio Pertumbuhan. Rasio pertumbuhan Pemerintah Provinsi Sulawesi Utara dapat dihitung sebagai berikut:

$R P=P n-P o / P o x 100 \%$

$\mathrm{RP}=$ Rasio Pertumbuhan

$\mathrm{Pn}=$ Data yang di hitung pada tahun ke $\mathrm{n}$.

P0 = Data yang di hitung pada tahun ke 0 , tahun sebelum $\mathrm{n}$.

Tabel 4. Rasio Pertumbuhan Penerimaan Pemerintah Provinsi Sulawesi Utara Tahun Anggaran 2014 - 2018 (dinyatakan dalam ribuan rupiah)

\begin{tabular}{|c|c|c|c|c|c|c|}
\hline \multirow{2}{*}{ Keterangan } & \multicolumn{5}{|c|}{ Tahun } & \multirow{2}{*}{$\begin{array}{c}\text { Rata-rata } \\
(\%)\end{array}$} \\
\hline & 2014 & 2015 & 2016 & 2017 & 2018 & \\
\hline Pendapatan Daerah & 2.320 .810 .783 & 2.527 .959 .070 & 2.885 .186 .111 & 3.731 .901 .683 & 3.779 .295 .766 & \\
\hline Pertumbuhan & - & 8,90 & 14,10 & 29,30 & 1,27 & 13,40 \\
\hline PAD & 937.681 .927 & 1.012 .945 .961 & 981.044 .550 & 1.146 .674 .828 & 1.168 .433 .686 & \\
\hline Pertumbuhan & - & 8,02 & $-3,15$ & 16,90 & 1,89 & 5,91 \\
\hline Dana Perimbangan & 1.093.949.318 & 1.173 .041 .387 & 1.880.906.287 & 2.508 .041 .622 & 2.586 .412 .080 & \\
\hline Pertumbuhan & - & 7,22 & 60,30 & 33,30 & 3,12 & 26,00 \\
\hline Lain-lain Pendapatan & & & & & & \\
\hline Yang Sah & 289.179 .538 & 341.971 .722 & 23.235 .274 & 77.185 .233 & 24.450 .000 & \\
\hline Pertumbuhan & - & 18,30 & $-93,20$ & 97,00 & $-68,32$ & $-46,22$ \\
\hline
\end{tabular}

Berdasarkan Tabel 4, perhitungan pertumbuhan penerimaan pada Pemerintah Daerah Provinsi Sulawesi Utara dinyatakan dalam bentuk rasio pertumbuhan keuangan dan diketahui bahwa laju pertumbuhan Pendapatan Daerah (PD) Provinsi Sulawesi Utara tahun anggaran 2014 - 2018 adalah:

- Pertumbuhan Pendapatan daerah Provinsi Sulawesi Utara selama tahun anggaran 2014 - 2018 rata - rata pertahun hanya $13,40 \%$. Berdasarkan Skala Interval untuk Kriteria Penilaiannya, Pendapatan Daerah di Provinsi Sulawesi Utara ada pada kategori Kurang.
Pertumbuhan keuangan Pendapatan Asli Daerah di Provinsi Sulawesi Utara ratarata pertahun dalam bentuk prosentase dari tahun 2014 - 2018, hanya sebesar $5,91 \%$, dalam ukuran skala interval pertumbuhan PAD masih sangat kurang. - Pertumbuhan penerimaan dari Dana Perimbangan untuk rata-rata pertahunnya sebesar 26\%, ada dalam kriteria penilaian Sedang untuk pertumbuhannya. Pertumbuhan Lainlain Pendaptan Yang Sah, rata-rata pertahunnya tidak mengalami pertumbuhan karena minus (-) 46,22\%. 
Tabel 5. Rasio Pertumbuhan Pengeluaran (Belanja) Pemerintah Provinsi Sulawesi Utara Tahun Anggaran 2014 - 2018 (dinyatakan dalam ribuan rupiah)

\begin{tabular}{|c|c|c|c|c|c|c|}
\hline \multirow{2}{*}{ Keterangan } & \multicolumn{5}{|c|}{ Tahun } & \multirow{2}{*}{$\begin{array}{c}\text { Rata-rata } \\
(\%)\end{array}$} \\
\hline & 2014 & 2015 & 2016 & 2017 & 2018 & \\
\hline Belanja Operasional & 1.357 .382 .942 & 1.597 .643 .233 & 1.652.297.772 & 2.344.089.708 & 2.521 .304 .007 & \\
\hline Pertumbuhan & - & 17,70 & 03,42 & 41,86 & 07,56 & 17,64 \\
\hline Belanja Modal & 506.723 .318 & 757.277.049 & 745.899 .590 & 757.829 .988 & 1.146 .111 .035 & \\
\hline Pertumbuhan & - & 49,44 & $-02,00$ & 02,00 & 51,23 & 25,16 \\
\hline Belanja Tidak Terduga & 1.586 .104 & 429.250 & 500.200 & 1.000 .000 & 7.500 .000 & \\
\hline Pertumbuhan & - & $-73,00$ & 16,52 & 99,92 & 6,5 & 12,36 \\
\hline Belanja Transfer & 363.792 .023 & 337.734 .260 & 402.447 .834 & 477.652 .097 & 506.784 .140 & \\
\hline Pertumbuhan & - & $-07,16$ & 19,16 & 18,68 & 06,09 & 9,19 \\
\hline
\end{tabular}

Berdasarkan perhitungan Rasio Pertumbuhan untuk Belanja Pemerintah Provinsi Sulawesi Utara, tahun anggaran 2014 - 2018 pada Tabel 5, dapat dilihat bahwa Belanja Operasional untuk pertumbuhannya pertahun ada pada ratarata $17,64 \%$ untuk ukuran skala interval ada pada penilaian masih kurang pertumbuhannya dan Pertumbuhan Belanja Modal ada pada rata-rata $25,16 \%$ ada dalam kriteria penilaian Sedang dalam pertumbuhan belanjanya, sedangkan Pertumbuhan Belanja Tidak Terduga ada pada rata-rata $12,36 \%$ ada dalam kategori kurang dalam pemanfaatan belanja dan Pertumbuhan Belanja Transfer hanya mencapai 9,19\%, dalam kategori sangat kurang.

\section{Pembahasan}

\section{Perkembangan}

Kemampuan

Keuangan Pemerintah Daerah Provinsi Sulawesi Utara dilihat dari Tingkat Kemandirian Keuangan. Berdasarkan perhitungan Rasio Kemandirian Keuangan, ditahun 2014 tingkat kemandiriannya ada pada angka $85,70 \%$ termasuk pada kategori tinggi untuk kemampuan keuangannya berdasarkan skala interval pada pola hubungan, karena ada pada angka antara $>75 \%-100 \%$. Ditahun 2015 ada kenaikan sedikit dan masih pada kategori tinggi karena tingkat kemandiriannya mencapai 86,30\%. Namun di tahun 2016 sampai dengan tahun 2018 tingkat kemandiriannya ada penurunan karena hanya mencapai angka 45,20\% dan berada pada skala interval antara $>25 \%$ $50 \%$ pada kategori rendah. Untuk perhitungan rata-rata pertahun penerimaannya, berdasarkan Rasio
Kemandirian Keuangan ada pada angka 63\%. Jika dilihat pada skala interval pola hubungan, angka rata-rata pertahun 63\% ada diantara $>50-75 \%$, maka dengan demikian, kemampuan keuangan Pemerintah Provinsi Sulawesi Utara masih ada pada kategori sedang dan ada pada pola hubungan yang Partisipatif yang artinya peranan pemerintah pusat semakin berkurang, dikarenakan Pendapatan Asli Daerah Pemerintah Provinsi Sulawesi Utara bisa dikatakan masih cukup mampu berkontribusi terhadap Pendapatan Daerah. Dengan melihat hasil analisis Rasio Keuangan untuk Realisasi penerimaannya terhadap besarnya Pendapatan Asli Daerah dibandingkan dengan penerimaan dana transfer, dapat dikatakan bahwa PAD Provinsi Sulawesi Utara yang mulanya pada tahun 2014 dan 2015 masih termasuk tinggi dalam penerimaannya dan masih mampu mengimbangi penerimaannya dengan Dana Transfer, namun pada tahun anggaran 2016 - 2018 PAD tidak terjadi perkembangan yang signifikan sehingga mengalami dampak terhadap kemandirian keuangannya yang makin menurun yang mulanya tinggi kemampuan PAD-nya pada akhirnya hanya menjadi sedang untuk rata-rata pertahunnya.

Perkembangan Kemampuan Keuangan Pemerintah Daerah Provinsi Sulawesi Utara dilihat dari Tingkat Ketergantungan Keuangan. Rasio Ketergantungan keuangan daerah dapat dihitung dengan membuat perbandingan antara jumlah pendapatan yang diterima dari transferan dana eksternal dengan total pendapatan daerah yang diterima. Berdasarkan hasil perhitungan rasio 
ketergantungan keuangan daerah terhadap kemampuan keuangan darah pemerintah Provinsi Sulawesi Utara terus terjadi peningkatan dalam pendapatannya melalui dana transferan dari pihak eksternal. Pada tahun 2014 transferan dana dari pusat sebesar 47,1\% hanya pada tahun 2015 ada penurunan kurang lebih $1 \%$ dari tahun sebelumnya sehingga menjadi 46,4\% namun pada tahun-tahun berikutnya terus terjadi peningkatan terhadap pendapatan daerah melalui dana perimbangan ini karena tahun 2016 sampai pada tahun 2018 Pemerintah Provinsi Sulawesi Utara mendapatkan dana transferan dari pihak luar mencapai angka tertinggi di tahun 2018 berjumlah 68,4 \% dan untuk rata-rata penerimaannya pertahun berdasarkan perhitungan Rasio Ketergantungan Keuangan Daerah ada pada pencapaian pada angka 58,86\%. Dengan demikian berdasarkan ukuran skala interval kriteria penilaian untuk angka $>50 \%$ ada pada kriteria penilaian yang sangat tinggi. Artinya Ketergantungan Keuangan Daerah Pemerintah Provinsi Sulawesi Utara masuk pada kriteria penilain masih sangat tinggi ketergantungannya terhadap dana transfer dari pusat.

\section{Perkembangan Kemampuan} Keuangan Pemerintah Daerah Provinsi Sulawesi Utara dilihat dari Derajat Desentralisasi Fiskal. Rasio Derajat Desentralisasi fiskal ini digunakan untuk melihat kemampuan keuangan daerah pemerintah provinsi Sulawesi Utara terhadap Pendapatan Asli Daerah (PAD) sebagai sumber pendapatan yang dikelola sendiri oleh daerah terhadap total penerimaan daerah karena semakin tinggi kontribusi Pendapatan Asli Daerah (PAD), maka semakin tinggi pula kemampuan pemerintah daerah dalam menyelenggarakan desentralisasi. Berdasarkan perhitungan analisis Rasio Derajat Desentralisasi Fiskal Pemerintah Provinsi Sulawesi Utara, untuk tahun 2014 dan tahun 2015 ada pada angka yang sama $40 \%$, di tahun 2016 turun menjadi 34\% dan pada tahun 2017 - 2018 menurun sampai pada angka yang sama juga $31 \%$, dengan perhitungan rata-rata Derajat Desentralisasi pertahun sebesar $35,2 \%$.
Artinya Derajat Desentralisasi bila pada angka rata-rata pertahunnya 35,2 berdasarkan skala interval ada dalam penilaian yang cukup, meskipun masih tetap bergantung pada sumber keuangan yang berasal dari dana transferan pemerintah pusat.

\section{Perkembangan Kemampuan} Keuangan Pemerintah Daerah Provinsi Sulawesi Utara dilihat dari Pertumbuhannya. Keuangan daerah yang mengalami perkembangan setiap tahunnya terlebih peningkatan terhadap Pendapatan Asli Daerahnya, menunjukan bahwa daerah tersebut mengalami kemampuan keuangan dalam menyelenggarakan pemerintahan yang ada. Berdasarkan hasil analisis Rasio Pertumbuhan Pendapatan Daerah, menunjukan bahwa Pendapatan Daerah Provinsi Sulawesi Utara untuk APBD 2014 - 2018 hanya mengalami perkembangan rata-rata pertahunnya $13,40 \%$ dalam kriteria penilaian masih kurang, dikarenakan PAD untuk tahun 2014-2018 hanya memiliki ratarata pertumbuhannya pada angka 5,91\% dinilai masih sangat kurang berdasarkan skala interval sedangkan Dana Perimbangan rata-rata pertahunnya $26 \%$, dinilai Sedang untuk pertumbuhannya, dan sumber pendapatan daerah yang lain juga seperti Lain-lain Pendapatan yang Sah belum mengalami perkembangan untuk mendukung pendapatan daerah pemerintah provinsi Sulawesi Utara, jika dilihat pada perhitungan rasio pertumbuhan pertahunnya yang mengalami minus (-) 46,22\%. Artinya dari hasil perhitungan rasio pertumbuhan terhadap Sumber-sumber Pendapatan Daerah Pemerintah Provinsi Sulawesi Utara tahun 2014 - 2018 mengalami perkembangan yang tidak signifikan karena kriteria penilaiannya masih termasuk kurang. Dalam hal ini, Pertumbuhan Penerimaan Dana Transfer yang masih mendominasi Pendapatan Daerah dalam pertumbuhan pertahunnya. Untuk Belanja Daerah tahun anggaran 2014 - 2018 yang total belanjanya berjumlah Rp.15.485.984.626.000, jika dihitung dengan prosentase Belanja Operasional/Belanja Modal dibagi dengan Total Belanja Daerah, maka ditemukan hasil 
bahwa Belanja Operasional lebih Besar $61,16 \%$ penggunaannya daripada Belanja Modal yang hanya menggunakan 25,27\% dari total belanja daerah kemudian diikuti dengan belanja-belanja lainnya yang sangat kecil. Jika diukur berdasarkan skala interval, Belanja Operasional $61,16 \%$ dinilai pada kategori sangat tinggi karena ada pada skala $>50.00 \%$. Sedangkan untuk Belanja Modal yang hanya $25,27 \%$ dinilai pada kategori sedang karena ada pada skala 20,01\% 30,00\%. Realisasi Belanja Operasional daerah Pemerintah Provinsi Sulawesi Utara yang terdiri dari belanja pegawai, belanja barang, bunga, subsidi, hibah (Uang, barang dan Jasa) dan bantuan Sosial (uang dan barang), berdasarkan hasil analisis Belanja Pegawai lebih mendominasi penggunaannya sampai mencapai Rp. 4.060.337.917.000, kemudian Belanja Barang dan Jasa sebesar Rp. 3.222.365.971.000, diikuti oleh Belanja Hibah yang berjumlah Rp. 2.156.681.722.000. Dengan demikian dapat dikatakan bahwa Pemerintah Provinsi Sulawesi Utara lebih cenderung menggunakan dana yang ada dalam Anggaran Pendapatan dan Belanja Daerah untuk Belanja Operasional yang digunakan begitu besar untuk Belanja Pegawai, Belanja Barang dan Jasa, serta Belanja Hibah. Hal ini mengakibatkan Belanja Modal lebih kecil. Ketika Belanja Modal kecil tentu akan merugikan masyarakat, sebab pembangunan infrastruktur untuk masyarakat tidak maksimal karena Belanja Modal jadi terbatas. Olehkarena itu penting pemerintah Provinsi Sulawesi Utara agar dapat memangkas Belanja Pegawai begitu juga dalam penggunaan dana rutin di setiap Satuan Kerja Perangkat Daerah yang di dalamnya termasuk dana perjalanan dinas baik untuk staf maupun pejabatnya itu harus ditekan untuk mengurangi belanja pegawai tersebut kemudian dapat memperbesar Belanja Modal untuk mendorong peningkatan akan Pendapatan Asli Daerah maka dengan demikian Anggaran Pendapatan Belanja Daerah (APBD) akan semakin sehat. Sekalipun untuk perhitungan berdasarkan Rasio Pertumbuhan terhadap Belanja Operasional tahun $2014-2018$ penggunaan belanja rata-rata pertahunnya hanya 17,64\% dalam skala interval untuk kriteria penilaian masih kurang tapi jika dilihat dari anggaran Belanja Daerahnya, Belanja Operasional masih sangat tinggi menggunakan Belanja Daerah, sedangkan untuk Belanja Modal yang rata-rata pertahunnya ada pada angka $25,27 \%$ jika diukur menggunakan skala interval, maka kriteria penilaiannya ada pada kategori sedang pertumbuhan belanjanya. Memang, dari data yang ada kecenderungan dari tahun ke tahun, belanja modal daerah memperlihatkan terjadi peningkatan sekalipun Belanja Pegawai Pemprov Sulawesi Utara masih lebih besar. Namun, peningkatan tersebut harus diekselerasi agar dapat lebih konsisten memberi dorongan pada sektor ekonomi dan selain itu bisa lebih bermanfaat bagi masyarakat daripada APBD dihabiskan untuk pembayaran gaji pegawai Pemerintah Daerah.

\section{Kesimpulan dan saran Kesimpulan}

Perkembangan Kemampuan Keuangan Pemerintah Daerah Provinsi Sulawesi Utara, tahun 2014 - 2018 dilihat dari Rasio Tingkat Kemandirian Keuangannya, dapat terlihat dari besarnya PAD dibandingkan dengan penerimaan dana transfer, hal tersebut dapat tergambarkan seberapa besar perkembangan kemampuan keuangan daerah Pemerintah Provinsi Sulawesi Utara, yang pencapaian tingkat kemandiriannya ada pada angka 63\% pada kriteria penilaian sedang untuk kemampuan keuangannya dengan memiliki pola hubungan partisipatif dimana peranan pemerintah pusat semakin berkurang. Perkembangan Kemampuan Keuangan Pemerintah Daerah Provinsi Sulawesi Utara, dilihat dari Tingkat Ketergantungannya masih termasuk sangat tinggi sekalipun peranan pemerintah pusat makin berkurang namun penerimaan dana transfer rata-rata pertahunnya masih mencapai angka 58,86\% dan berdasarkan Kriteria Penilaian untuk angka rata-rata pertahunnya $58,86 \%$, tingkat kemampuan keuangan daerahnya ada pada penilaian masih sangat tinggi.

Hasil perhitungan Rasio Ketergantungan menunjukan bahwa Pendapatan Asli Daerah 
(PAD) masih mempunyai kemampuan yang masih cukup kontribusinya terhadap pendapatan daerah dalam menyelenggarakan desentralisasi karena berdasarkan perhitungan berada pada angka 35,2\%, dimana kriteria penilaian untuk skala interval antara angka 30.01\% - 40.00\% berada pada penilaian yang cukup mampu, sekalipun perkembangan PAD masih belum signifikan dibandingkan Penerimaan dari dana transfer. Untuk Pendapatan Daerah Provinsi Sulawesi Utara, Pertumbuhan dalam penerimaannya setiap tahun selang tahun 2014 - 2018 untuk penerimaan rata-rata pertahunnya masih termasuk kurang dikarenakan pertumbuhan Pendapatan Asli Daerah dalam penerimaan rata-rata pertahunnya diniai Sangat Kurang, sedangkan untuk Dana Perimbangan penerimaannya setiap tahun ada pada penilaian Sedang dan Lain-lain Pendapatan yang sah tidak mengalami pertumbuhan. Artinya pertumbuhan terhadap penerimaan dana perimbangan masih menguasai Pendapatan Daerah sedangkan untuk Belanja Daerah dikuasai oleh Belanja Operasional daripada Belanja Modal. Dengan pertumbuhan Pendapatan Asli Daerah yang masih kurang setiap tahunnya, maka dengan demikian Pemerintah Daerah Provinsi Sulawesi Utara akan terus memiliki ketergantungan terhadap dana transfer dari pusat karena sebagian besar habis untuk belanjaoperasional yang didalamnya adalah belanja pegawai. Idealnya Belanja Modal dari tahun ke tahun harus ditingkatkan dan dianggarkan lebih besar daripada belanja Pegawai, agar pembangunan di Provinsi Sulawesi Utara lebih terasa dan anggarannya pro rakyat.

\section{Saran}

Melakukan peningkatan pendapatan dari sumber-sumber pedapatan asli daerah dengan cara intensifikasi maupun ekstensifikasi. Cara intensifikasi dengan memperbaiki pengelolaan keuangan melalui pemungutan pajak dan retribusi sedangkan cara ekstensifikasi dapat dilakukan dengan mengidentifikasi setiap potensi daerah yang ada untuk memunculkan peluang yang baru sebagai sumber pendapatan asli daerah, sehingga Pemerintah Daerah Provinsi
Sulawesi Utara bisa mencapai kemandirian keuangannya dan dapat meminimalisasi ketergantungan keuangannya terhadap dana transfer dari pemerintah pusat. Berani memangkas Belanja Pegawai yang begitu besar dan meningkatkan Belanja Modal sehingga Provinsi Sulawesi Utara memiliki anggaran yang pro rakyat. Bagi Penelitian Selanjutnya dapat mengkaji atau meneliti kemampuan keuangan Pemerintah Provinsi Sulawesi Utara dengan analisis-analisis rasio keuangan lainnya, agar melalui penelitian yang sinkron dan berkesinambungan bisa menjadi jawaban bagi pemerintah Provinsi Sulawesi Utara untuk menghasilkan perkembangan kemampuan keuangan lebih maksima lagi dan kemajuan pembangunan di daerah tercinta ini.

\section{Daftar Pustaka}

Halim, A. (2008). Akuntasi Keuangan Daerah, Edisi Revisi 3. Jakarta : Salemba Empat.

Helfert, E. (2000). Teknik analisa Keuangan. Jakarta : Erlangga.

Mahmudi. (2010). Manajemen Kinerja Sektor Publik. Yogyakarta : UPP STIM YKPN

Munawir, S. (1997). Analisa Laporan Keuangan, Edisi Ke Empat, Cetakan Ke tujuh, Liberty. Yogyakarta.

Peraturan Menteri Dalam Negeri Republik Indonesia Nomor 13 Tahun 2006 tentang Pedoman Pengelolaan Keuangan Daerah. Jakarta, Kementerian Dalam Negeri Republik Indonesia.

Peraturan Pemerintah Republik Indonesia Nomor 24 Tahun 2005 tentang Standarisasi Akuntansi Pemerintahan.

Peraturan Pemerintah Republik Indonesia Nomor 58 Tahun 2005 tentang Pengelolaan Keuangan Daerah. Jakarta, Kementerian Dalam Negeri Republik Indonesia.

Peraturan Pemerintah Republik Indonesia Nomor 12 Tahun 2019 tentang Pengelolaan Keuangan Daerah.

Peraturan Pemerintah Republik Indonesia Nomor 105 Tahun 2000 tentang Pengelolaan dan Pertanggungjawaban Keuangan Daerah.

Pontoh, W. (2013). Akuntansi Konsep dan Aplikasi. Jakarta: Halaman Moeka.

Undang-Undang Republik Indonesia Nomor 23 Tahun 2014 tentang Pemerintahan Daerah. Jakarta, Direktorat Jenderal Otonomi Daerah.

Undang-Undang Republik Indonesia Nomor 33 Tahun 2004 tentang Perimbangan Keuangan antara Pemerintah Pusat dan Pemerintah Daerah. Jakarta, Direktorat Jenderal Otonomi Daerah.

Undang-Undang Republik Indonesia Nomor 32 Tahun 2004 Dalam Penjelasan Umum Pasal 156 Ayat (1) tentang Keuangan Daerah. Jakarta, Direktorat Jenderal Otonomi Daerah. 
Undang-Undang Republik Indonesia Nomor 33 Tahun 2014 tentang Pengelolaan Keuangan Daerah dalam rangka Desentralisasi. Bagian Kesatu, Asas Umum Pasal 66. Jakarta, Direktorat Jenderal Otonomi Daerah.

Savitry., E., Saleh., H., A. \& Arifin., I. (2011). Analisis kemampuan keuangan daerah dalam pelaksanaan otonomi daerah tahun 2007 -2011 di Kota Makassar. Government: Jurnal Ilmu Pemerintahan, 4(1), 23-24. http://journal.unhas.ac.id/index.php/governme $\mathrm{nt} /$ article/view/1570 